\title{
Responses of eelgrass Zostera marina seedlings to reduced light
}

\author{
Joanne C. Bintz ${ }^{1, *}$, Scott W. Nixon ${ }^{2}$ \\ ${ }^{1}$ Ocean Studies Board, National Academy of Sciences, 2101 Consitution Av. NW, HA 470, Washington, DC 2041, USA \\ ${ }^{2}$ Graduate School of Oceanography, University of Rhode Island, PO Box 200, South Ferry Road, Narragansett, \\ Rhode Island 02882, USA
}

\begin{abstract}
We subjected seedlings of Zostera marina L. to High (72\%), Medium (23\%), and Low $(10 \%)$ daily irradiance (mean daily PAR of $24.4,7.9$, and $3.3 \mathrm{E} \mathrm{m}^{-2} \mathrm{~d}^{-1}$ respectively) over $12 \mathrm{wk}$. We measured plant response in terms of survivorship, lateral shoot production, morphology, growth rate, photosynthesis and respiration, and leaf pigment concentration. Decreasing the light available to eelgrass seedlings from 72 to $23 \%$ resulted in a reduction of lateral shoot formation, lower plant biomass, and longer and wider leaves. Shoot area, growth rate, and pigment concentrations remained similar. A reduction of incident light to $10 \%$ decreased survival to $74 \%$ and had a negative effect on shoot growth, size, and above- and belowground biomass. Pigment concentrations increased with respect to seedlings raised at medium light. In general, the responses of seedlings to reduced light are similar to those reported for mature $Z$. marina. Rapid expansion of seedling patches can only occur at irradiance levels greater than $7.9 \mathrm{E} \mathrm{m}^{-2} \mathrm{~d}^{-1}$. Morphological changes resulting from exposure to mean daily PAR levels of less than $8 \mathrm{E} \mathrm{m}^{-2} \mathrm{~d}^{-1}$ such as thinner leaves and low belowground biomass, have serious implications for decreased seedling survival in the field.
\end{abstract}

KEY WORDS: Eelgrass $\cdot$ Seagrass seedlings $\cdot$ Light $\cdot$ Zostera marina $\cdot$ Shade adaptation Resale or republication not permitted without written consent of the publisher

\section{INTRODUCTION}

Temperate eelgrass Zostera marina L. meadows are produced and maintained largely by the asexual extension and branching of rhizomes (Phillips et al. 1983, Olesen \& Sand-Jensen 1994a). However, several studies have documented the importance of seeds and seedlings in establishing patches in bare areas within and outside of existing beds (Orth \& Moore 1983, Harrison 1987, Olesen \& Sand-Jensen 1994a,b, Olesen 1999 and others). In addition, in several areas of the world, annual eelgrass populations are maintained entirely by the production of seeds and seedlings (Keddy \& Patriquin 1978, Harlin et al. 1982, McMillan 1983, Harrison 1991). The production of seeds within an eelgrass meadow is considerable and may reach $70000 \mathrm{~m}^{-2}$ (van Lent \& Vershuure 1994, Fishman \&

*E-mail: jbintz@nas.edu
Orth 1996, van Katwijk et al. 1998). For this reason, using seeds for restoration and mitigation may hold great potential (Harwell \& Orth 1999, Granger et al. 2000). Seedling germination is between 30 and $90 \%$ (Churchill 1983, Hootsmans et al. 1987, van Lent \& Verschuure 1994, Granger et al. 2000), but seedling mortality is often substantial (Robertson \& Mann 1984, Duarte \& Sand-Jensen 1990, Olesen \& Sand-Jensen 1994a, de Jonge et al. 1996). The ultimate success of germinated seedlings and the formation of viable beds appears to depend upon several factors, including sediment burial, light attenuation, nutrient limitation, and initial patch size (Churchill 1983, Duarte \& SandJensen 1990, Orth et al. 1994).

Using transplanted seedlings and sowing seeds are both being explored as viable restoration techniques in the Dutch Wadden Sea (de Jonge et al. 2000). However, an obstacle to the use of these techniques is that much of the basic quantitative information needed to assess the potential of different sites is unavailable 
(de Jonge et al. 1996, van Katwijk et al. 2000). Virtually all of our knowledge of Zostera marina physiology and environmental requirements is derived from studies of mature plants in established populations (Backman \& Barilotti 1976, Bulthuis 1983, Dennison \& Alberte 1982, 1985, Olesen \& Sand-Jensen 1993). An example is the relationship between plant growth and survival and the availability of photosynthetically active radiation (PAR). The responses of mature, established plants to changes in light exposure have been well documented (e.g. Dennison \& Alberte 1982, 1985, 1986, Short 1991, Olesen \& Sand-Jensen 1993). While these studies have been integral to understanding the role of light in the maintenance of eelgrass meadows, there have been only a few studies on the response of young, seed generated plants to changes in PAR (Zimmerman \& Alberte 1996, van Katwijk et al. 1998).

To determine the survival and growth potential of seed generated Zostera, we subjected seedlings to a gradient of light exposure and measured their response in terms of survivorship, asexual reproductive success, production and respiration rates, morphology, growth rate, and leaf pigment concentrations.

\section{MATERIALS AND METHODS}

Experimental system and design. SCUBA divers harvested seed-bearing shoots of Zostera marina in July and August of 1997, in Narragansett Bay, Rhode Island, USA $\left(41^{\circ} \mathrm{N}, 71^{\circ} \mathrm{W}\right)$. The plants were allowed to release their seeds in outdoor flowing seawater tanks adjacent to the lower bay. We separated seeds from the detrital remains of the spathe through several steps of screening and winnowing, and held the seeds in ambient flowing seawater for several months (Granger et al. 2000).

Seeds were planted in late December 1997. Four seeds were buried at $2 \mathrm{~cm}$ depth in individual $10.2 \mathrm{~cm}$

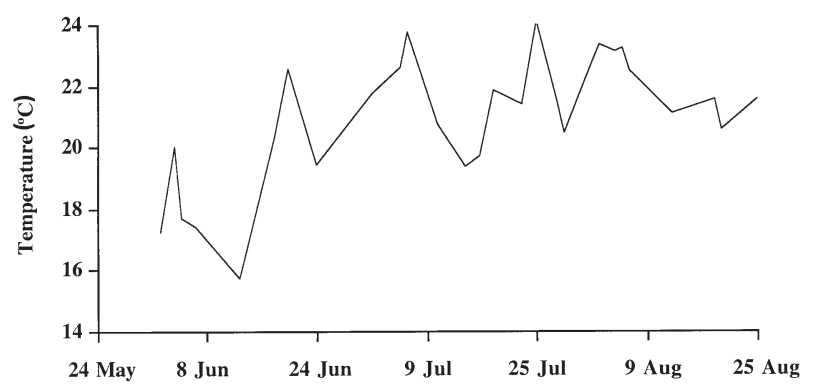

Fig. 1. Mean daily water temperature in experimental tanks. Temperature was recorded using continuous probes in conjunction with daily thermometer readings diameter pots in low organic $(0.17$ to $0.56 \%$ weight loss on ignition at $550^{\circ} \mathrm{C}$ ) sandy sediment collected in Block Island Sound. We allowed the seeds to germinate in outdoor tanks with flowing seawater $50 \mathrm{~cm}$ deep, under conditions of ambient light and temperature. Seedlings began emerging on January 21, 1998. Each of 3 light treatments was apportioned 80 pots, giving a total of 240 pots.

By May 15, the seedlings reached a mean height of $4 \mathrm{~cm}$ and we thinned the plants to leave 1 seedling per pot before moving them to outdoor tanks with a water depth of about $80 \mathrm{~cm}$ over the sediment surface. Every week the tank walls were scrubbed clean of periphyton, and epiphytes were gently removed from the leaves by hand. The water column remained clear throughout the experiment as water continually flowed through the tanks. Salinity was measured 2 to 3 times per week with a digital salinometer, and varied between 29 and $32 \mathrm{psu}$. The experiment lasted for about 12 wk, from May 25 through August 20, 1998. Mean daily water temperatures during this period ranged from 16 to $24^{\circ} \mathrm{C}$ (Fig. 1).

The minimum light requirement for mature Zostera marina appears to lie between 8 and $30 \%$ of incident PAR (Duarte 1991, Dennison et al. 1993, van Katwijk et al. 1998). We used neutral density, greenhouse shade screens placed over the water to establish experimental conditions in which seedlings were exposed to $72 \%$ (high), 23\% (medium) and 10\% (low) of incoming irradiance at the sediment surface. Irradiance was measured at the base of the plants with a LI-COR 2 pi quantum underwater sensor and a LI-1000 data logger (LI-COR, Lincoln, NE). The high light treatment was not screened so that attenuation was due solely to the overlying water.

Hourly light data were collected by the Marine Ecosystems Research Laboratory with a LI-1000 data logger located on the dock at the Graduate School of Oceanography. These data were used with the respective attenuation coefficients to calculate mean daily quantum flux (PAR, E m ${ }^{-2} \mathrm{~d}^{-1}$ ) at the sediment surface for each treatment over the course of the $12 \mathrm{wk}$ experiment (Table 1).

Light climate. Mean daily PAR for the high light treatment was about 3 times greater than that received 
in the medium light treatment, and about 7 times greater than in the low light treatment (Table 1). Seedlings grown at the highest light level received at least $100 \mu \mathrm{E} \mathrm{m}^{-2} \mathrm{~s}^{-1}$ for more than $6 \mathrm{~h} \mathrm{~d}^{-1}$ on nearly every day of the experiment (Table 1). Seedlings in the low treatment never received $100 \mu \mathrm{E} \mathrm{m}^{-2} \mathrm{~s}^{-1}$ for more than $10 \mathrm{~h} \mathrm{~d}^{-1}$.

Survivorship, reproduction, morphology and growth. Growth and leaf production rates were calculated each month from June to August by randomly selecting 16 plants from each treatment and piercing at the top of the youngest sheath through all existing leaves of the primary shoot, using the method of Kentula \& McIntire (1986). Marked seedlings were collected approximately 20 d later. Following photosynthetic production and respiration incubations (see below), seedlings were rinsed with deionized water, and dissected by separating the leaves at the top of the sheath and from the rhizome at the top of the newest rhizome node. The length and width of each leaf from the top of the sheath to the tip of the leaf was recorded for both primary and lateral shoots. Old leaves had clearly visible piercing scars and new leaves were unscarred. The distance from the top of the sheath to the pierce scar was considered to be new growth. The new growth was multiplied by the leaf width, summed for all new leaf material, and divided by the number of days since marking to get growth as $\mathrm{cm}^{2}$ shoot $^{-1} \mathrm{~d}^{-1}$. Growth rates correspond to the primary shoot only (i.e. not laterals).

Shoot and root/rhizome material was dried at $65^{\circ} \mathrm{C}$ for a minimum of $48 \mathrm{~h}$ or until they reached a constant dry weight (DW). Any lateral shoots present were counted, measured, and weighed along with the primary shoot. Since we measured growth as the increase in leaf surface area, we developed a dry weight to surface area regression for each sampling period and for each treatment. We used the slope of the regression line to calculate the biomass of new material produced from the calculated new surface area (Table 2). Root/rhizome productivity was calculated as the dry weight of the entire rhizome from the top of the newest rhizome node divided by the number of days from the beginning of the experiment.

The plastochrone interval (PI) is the length of time between the generation of 2 successive new leaves on a single shoot and was calculated using the equation of Jacobs (1979). Relative growth rate (RGR) of shoots, which is the fraction of total above ground material produced per unit time, was calculated following van Lent \& Verschuure (1994). The leaf life span was calculated by multiplying the calculated PI by the mean number of standing leaves per shoot (F. T. Short pers. comm.).

Photosynthesis and respiration. Measurements of production and respiration rates were made on 3 occa- sions for each treatment, after approximately $10 \mathrm{~d}$ (June), $50 \mathrm{~d}$ (July), and $85 \mathrm{~d}$ (August) of treatment. Measurements were made under conditions of ambient bay water temperature and natural sunlight. The 16 randomly chosen seedlings which had been premarked for growth measurements $20 \mathrm{~d}$ before were removed from their pots by gently rinsing away the sediment, so that the shoot and rhizome remained intact. Individual whole plants with lateral shoots if present were placed in $300 \mathrm{ml}$ BOD bottles filled with filtered $(1 \mu \mathrm{m})$ Narragansett Bay water. Clear and opaque 'blank' bottles were used to correct for plankton metabolism. Of the 16 seedlings collected from each treatment, 4 were incubated in high light, 4 in medium light, 4 in low light and 4 were placed in dark bottles for determination of respiration rate.

Rates of net production and respiration were measured as change in oxygen concentration $\left(\mathrm{mg} \mathrm{l}^{-1}\right)$ in the BOD bottles during a $5 \mathrm{~h}$ incubation. Photosynthetic production rates were normalized to leaf surface area and respiration rates were normalized to whole plant biomass. Oxygen measurements were conducted before and after each incubation using a calibrated BOD oxygen probe (Model 5905, YSI Inc., Yellow Spring, OH) and a DO meter (YSI Model 58). Incubations were conducted during the same period of the day $(10: 00$ to $16: 00 \mathrm{~h})$ on sunny days. Mean light levels on the days that the experiments were conducted never varied by more than $62 \mu \mathrm{E} \mathrm{m}^{-2} \mathrm{~s}^{-1}$ in the high light treatment, $20 \mu \mathrm{E} \mathrm{m}^{-2} \mathrm{~s}^{-1}$ under the medium light screen, and $8 \mu \mathrm{E} \mathrm{m}^{-2} \mathrm{~s}^{-1}$ under the low light screen.

Leaf pigment content. Six of the 16 pierced shoots collected and dissected on each date over the course of the summer were also analyzed for pigment content. A $1 \mathrm{~cm}^{2}$ section from the tip of the youngest leaf was removed for analysis and weighed to the nearest $0.01 \mathrm{mg}$. If the youngest leaf contained less than $1 \mathrm{~cm}^{2}$, the difference was made up with a piece from the tip of the second youngest leaf. Chlorophyll extraction was carried out using the method of Dennison (1990).

Table 2. Slope $\left(\mathrm{r}^{2}\right)$ for linear regressions of dry weight (mg) versus surface area $\left(\mathrm{cm}^{2}\right)$ for each mo and each treatment used to calculate the amount of dry weight biomass produced over each marking period. $\mathrm{n} \approx 10$ plants

\begin{tabular}{|lccc|}
\hline Month & High light & Medium light & Low light \\
\hline Jun & $4.2(0.98)$ & $4.0(0.93)$ & $3.6(0.97)$ \\
Jul & $6.0(0.99)$ & $4.7(0.92)$ & $3.3(0.89)$ \\
Aug & $6.2(0.97)$ & $3.9(0.99)$ & $5.5(0.69)^{*}$ \\
${ }^{*}$ The low $\mathrm{r}^{2}$ for this regression is due to one point out of 8 \\
that deviates from the trend line. Excluding this point \\
raises the $\mathrm{r}^{2}$ to 0.94 but only changes the slope to 5.1 \\
\hline
\end{tabular}




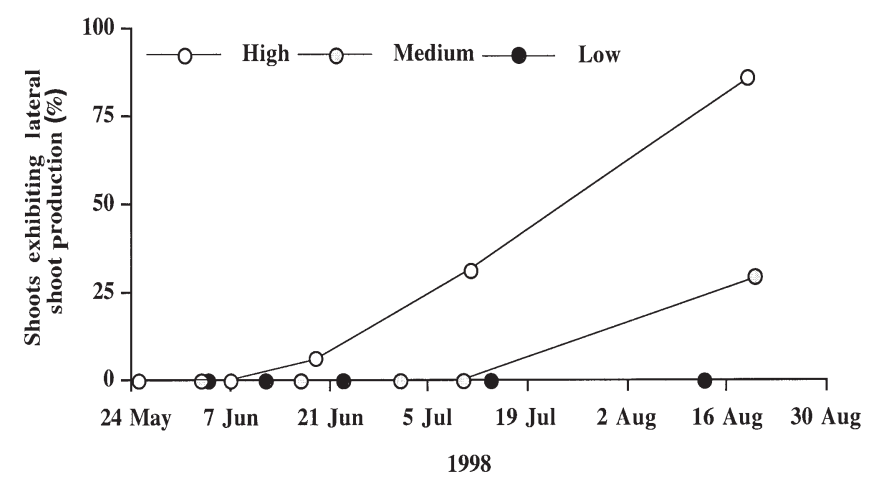

Fig. 2. Percentage of seedlings exhibiting vegetative reproduction in High, Medium and Low light over 12 wk. Each point represents a sample of 16 seedlings. May 25 was the initial conditon before experimental treatment

Absorbance at 645, 663 and $725 \mathrm{~nm}$ was determined with a DU 640 spectrophotometer (Beckman Instruments, Carlsbad, CA) on duplicate samples.

Statistical analysis. We used normal probability plots to test for normality on all of the data. None of the parameters were normally distributed except for chlorophyll a. A 1-way ANOVA on the ranked data (KruskalWallis test) was used to test for the effect of light level on photosynthesis, morphological, and growth parameters. If there was a significant difference $(p<0.05)$ between treatments, a post-hoc Bonferroni multiple comparison test was used ( $\mathrm{p}<0.016$ ) (SPSS Inc. 1998). A paired $t$-test of least significant difference followed by a Tukey pairwise comparison was used to test for the effect of light level on chlorophyll concentrations. All statistical analyses were performed in SAS (Cody \& Smith 1997).

\section{RESULTS}

Seedling survival was high in all treatments; $74 \%$ in the low, $94 \%$ in the medium, and $100 \%$ in the high light. Seedlings grown at high ambient light began producing lateral shoots within a few weeks of transfer to the experimental tanks, and $86 \%$ of the plants collected had produced at least 1 lateral shoot after $12 \mathrm{wk}$ (Fig. 2). In the medium light treatment, lateral shoot initiation was delayed, and it was completely suppressed in the low light treatment.

Seedlings that were exposed to high light for $12 \mathrm{wk}$ had significantly larger shoots, more below ground biomass (Fig. 3), and more leaves on the primary shoot compared to seedlings grown in low light (Table 3). After $12 \mathrm{wk}$, lateral shoots from the high light treatment comprised a mean of $23 \%$ of total leaf shoot weight and $28 \%$ of total leaf shoot area. Lateral shoots from the medium light treatment comprised a mean of $14 \%$ of total leaf shoot weight and $10 \%$ of total leaf shoot area.

Primary shoots grown at $23 \%$ incident light had significantly wider leaves and greater specific leaf area than seedlings from the other treatments (Table 3). However, they were not significantly different from seedlings grown at $72 \%$ light in the majority of morphological and growth parameters measured. A $90 \%$ reduction in light resulted in smaller shoots with less below ground biomass (Fig. 3). Growth rates of primary shoots and rhizomes were negatively affected (Table 3).

Seedlings grown in high light established a short and relatively constant plastochrone interval (PI) of 1 new leaf every 9 to $12 \mathrm{~d}$ throughout the experiment. Plants grown at medium light were able to produce a new leaf every $13 \mathrm{~d}$ in June and July, but after $12 \mathrm{wk}$, they were producing a new leaf only every $21 \mathrm{~d}$
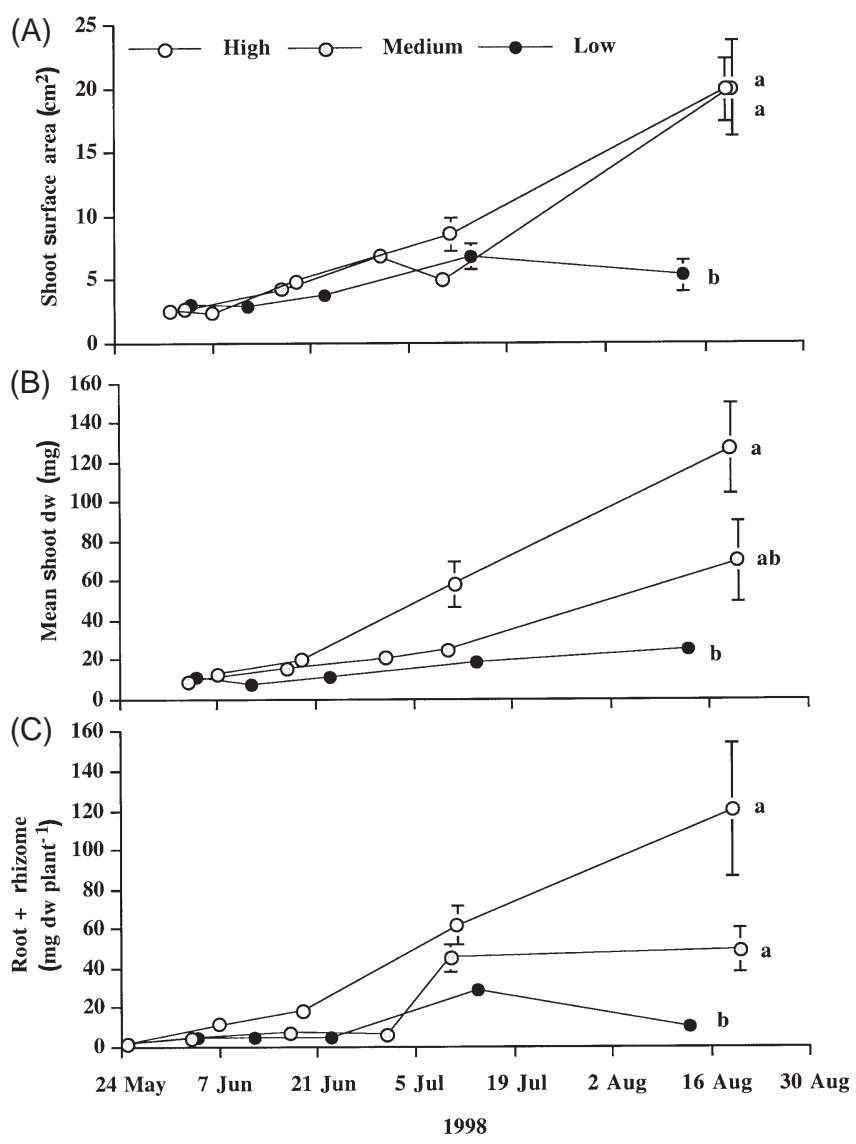

Fig. 3. Surface area and above- and belowground dry weight of seedlings grown in High, Medium and Low light over a 12 wk period. (A) Mean shoot surface area; (B) mean shoot dry weight; $(C)$ mean root + rhizome dry weight. Bars represent standard errors of the mean. Symbols followed by the same latter indicate no statistical difference at $12 \mathrm{wk}$. All parameters include lateral shoots 
Table 3. Physiological and morphological characteristics of Zostera marina seedlings after 12 wk exposure to high, medium, and low light. Values in rows followed by the same letter indicate no statistical difference between treatments. Data are means $( \pm$ SE)

\begin{tabular}{|c|c|c|c|}
\hline Variable & High & Medium & Low \\
\hline \multicolumn{4}{|l|}{ Seedling morphology } \\
\hline \multicolumn{4}{|l|}{ Shoot size including laterals } \\
\hline$\left(\mathrm{mg} \mathrm{dw}\right.$ seedling $\left.{ }^{-1}\right)$ & $126.5^{\mathrm{a}}(23)$ & $69.8^{\mathrm{ab}}(20)$ & $25.2^{\mathrm{b}}(5)$ \\
\hline$\left(\mathrm{cm}^{2}\right.$ seedling $\left.{ }^{-1}\right)$ & $19.9^{\mathrm{a}}(2.5)$ & $19.9^{\mathrm{a}}(3.7)$ & $5.3^{\mathrm{b}}(1.2)$ \\
\hline \multicolumn{4}{|c|}{ Below ground biomass including laterals } \\
\hline$\left(\mathrm{mg} \mathrm{dw}\right.$ seedling $\left.{ }^{-1}\right)$ & $120^{\mathrm{a}}(34)$ & $49^{\mathrm{a}}(11)$ & $10^{\mathrm{b}}(1)$ \\
\hline$\%$ Biomass below ground & $51^{\mathrm{a}}(3)$ & $43^{\mathrm{ab}}(3)$ & $30^{\mathrm{b}}(4)$ \\
\hline Root:shoot ratio ${ }^{\text {a }}$ & $1.14^{\mathrm{a}}(0.14)$ & $0.77^{\mathrm{a}}(0.10)$ & $0.48^{\mathrm{a}}(0.12)$ \\
\hline Whole plant biomass (mg) & $268^{\mathrm{a}}(55)$ & $119^{\mathrm{b}}(31)$ & $35^{\mathrm{b}}(6)$ \\
\hline No. of leaves primary shoot ${ }^{-1}$ & $4.5^{\mathrm{a}}(0.2)$ & $3.2^{\mathrm{ab}}(0.4)$ & $3.0^{\mathrm{b}}(0.2)$ \\
\hline Maximum leaf length $(\mathrm{cm})$ & $16.5^{\mathrm{a}}(1.4)$ & $26.2^{\mathrm{a}}(2.3)$ & $17.3^{\mathrm{a}}(2.7)$ \\
\hline Maximum leaf width $(\mathrm{cm})$ & $0.21^{\mathrm{b}}(0.02)$ & $0.28^{\mathrm{a}}(0.02)$ & $0.14^{\mathrm{c}}(0.01)$ \\
\hline Specific leaf area $\left(\mathrm{cm}^{2} \mathrm{mg} \mathrm{dw}^{-1}\right)$ & $0.16^{\mathrm{b}}(0.01)$ & $0.28^{\mathrm{a}}(0.02)$ & $0.19^{\mathrm{b}}(0.03)$ \\
\hline Mean no. of laterals seedling ${ }^{-1}$ & $1.2^{\mathrm{a}}(0.2)$ & $0.4^{\mathrm{b}}(0.2)$ & $0.0^{\mathrm{b}}(0.0)$ \\
\hline \multicolumn{4}{|c|}{ Growth and production of primary shoot } \\
\hline \multicolumn{4}{|c|}{ Shoot growth rate } \\
\hline$\left(\mathrm{cm}^{2}\right.$ shoot $\left.^{-1} \mathrm{~d}^{-1}\right)$ & $0.38^{\mathrm{a}}(0.04)$ & $0.43^{\mathrm{a}}(0.09)$ & $0.12^{\mathrm{b}}(0.04)$ \\
\hline$\left(\mathrm{mg} \mathrm{dw} \operatorname{shoot}^{-1} \mathrm{~d}^{-1}\right)$ & $2.24^{\mathrm{a}}(0.30)$ & $1.65^{\mathrm{a}}(0.35)$ & $0.46^{\mathrm{b}}(0.08)$ \\
\hline \multicolumn{4}{|l|}{ Relative growth rate } \\
\hline$\left(\mathrm{cm}^{2} \mathrm{~cm}^{-2} \mathrm{~d}^{-1}\right)$ & $0.027^{\mathrm{a}}(0.001)$ & $0.022^{\mathrm{a}}(0.002)$ & $0.019^{\mathrm{a}}(0.002)$ \\
\hline \multicolumn{4}{|l|}{ Rhizome productivity } \\
\hline$\left(\mathrm{mg} \mathrm{dw}\right.$ shoot $\left.^{-1} \mathrm{~d}^{-1}\right)$ & $1.64^{\mathrm{a}}(0.39)$ & $0.56^{\mathrm{ab}}(0.13)$ & $0.12^{\mathrm{b}}(0.02)$ \\
\hline PI (days) ${ }^{\mathrm{b}}$ & 11 & 21 & 20 \\
\hline Leaf life span (days) & 48 & 59 & 67 \\
\hline \multicolumn{4}{|l|}{ Leaf pigments of primary shoot } \\
\hline \multicolumn{4}{|l|}{ Chl a } \\
\hline$\left(\mathrm{mg} \mathrm{dm}^{-2}\right)$ & $2.60^{\mathrm{ab}}(0.16)$ & $1.96^{\mathrm{b}}(0.22)$ & $2.87^{\mathrm{a}}(0.23)$ \\
\hline \multicolumn{4}{|l|}{ Total chlorophyll $(a+b)$} \\
\hline$\left(\mathrm{mg} \mathrm{dm}^{-2}\right)$ & $3.74^{\mathrm{ab}}(0.22)$ & $2.97^{\mathrm{b}}(0.34)$ & $4.44^{\mathrm{a}}(0.35)$ \\
\hline Chl $a: b$ ratio & $2.12^{\mathrm{a}}(0.22)$ & $1.91^{\mathrm{b}}(0.01)$ & $1.83^{\mathrm{b}}(0.04)$ \\
\hline
\end{tabular}

(Table 3). Seedlings grown at low light displayed a prolonged and variable PI of $19 \mathrm{~d}$ in June, $14 \mathrm{~d}$ in July, and $20 \mathrm{~d}$ in August. After $12 \mathrm{wk}$ of treatment, seedlings grown at low light held their leaves $8 \mathrm{~d}$ longer than those at medium light, and $20 \mathrm{~d}$ longer than those at high light.

After 12 wk of shading, seedlings from the low light treatment had a significantly greater chlorophyll $a$ and total chlorophyll $(a+b)$ concentration $\left(\mathrm{mg} \mathrm{dm}{ }^{-2}\right)$ compared to seedlings grown in medium light (Table 3). However, seedlings maintained in low and medium light had a significantly lower ratio of chlorophyll $a$ to $b$ than seedlings grown in high light.

Short-term photosynthetic rates $\left(\mu \mathrm{mol} \mathrm{O} \mathrm{O}_{2} \mathrm{dm}^{-1} \mathrm{~min}^{-1}\right)$ were significantly lower in seedlings from the low light treatment versus the high and medium treatments in June, but not in July or August (Table 4). There were no significant differences in respiration rates $\left(\mu \mathrm{mol} \mathrm{O}_{2}\right.$
Table 4. Zostera marina. Net production and respiration rates in June, July and August of whole seedlings grown in High, Medium and Low light. Production $\left(\mu \mathrm{mol} \mathrm{O}_{2} \mathrm{dm}^{-2}\right.$ $\left.\mathrm{min}^{-1}\right)$ is normalized to leaf surface area. Respiration $\left(\mathrm{O}_{2} \mathrm{mg}\right.$ $\mathrm{dw}^{-1} \mathrm{~min}^{-1}$ ) is normalized to whole plant dry weight. Units are $\mu \mathrm{mol}$. Values in columns followed by the same letter indicate no statistical difference between treatments. Data are means $( \pm \mathrm{SE})$

\begin{tabular}{|c|c|c|c|}
\hline & Jun & Jul & Aug \\
\hline \multicolumn{4}{|c|}{ Net production } \\
\hline High & $2.65(0.39)^{\mathrm{a}}$ & $1.51(0.29)^{\mathrm{a}}$ & $3.48(0.18)^{\mathrm{a}}$ \\
\hline Medium & $2.21(0.21)^{\mathrm{ab}}$ & $2.12(0.12)^{\mathrm{a}}$ & $1.19(0.40)^{\mathrm{a}}$ \\
\hline Low & $0.96(0.24)^{\mathrm{b}}$ & $1.05(0.16)^{\mathrm{a}}$ & $1.65(0.48)^{\mathrm{a}}$ \\
\hline \multicolumn{4}{|c|}{ Respiration } \\
\hline High & $0.46(0.21)^{\mathrm{a}}$ & $0.55(0.12)^{\mathrm{a}}$ & $0.44(0.05)^{\mathrm{a}}$ \\
\hline Medium & No data & $0.36(0.16)^{\mathrm{a}}$ & $0.30(0.10)^{\mathrm{a}}$ \\
\hline Low & $0.66(0.07)^{\mathrm{a}}$ & $0.23(0.02)^{\mathrm{a}}$ & $0.27(0.04)^{\mathrm{a}}$ \\
\hline
\end{tabular}



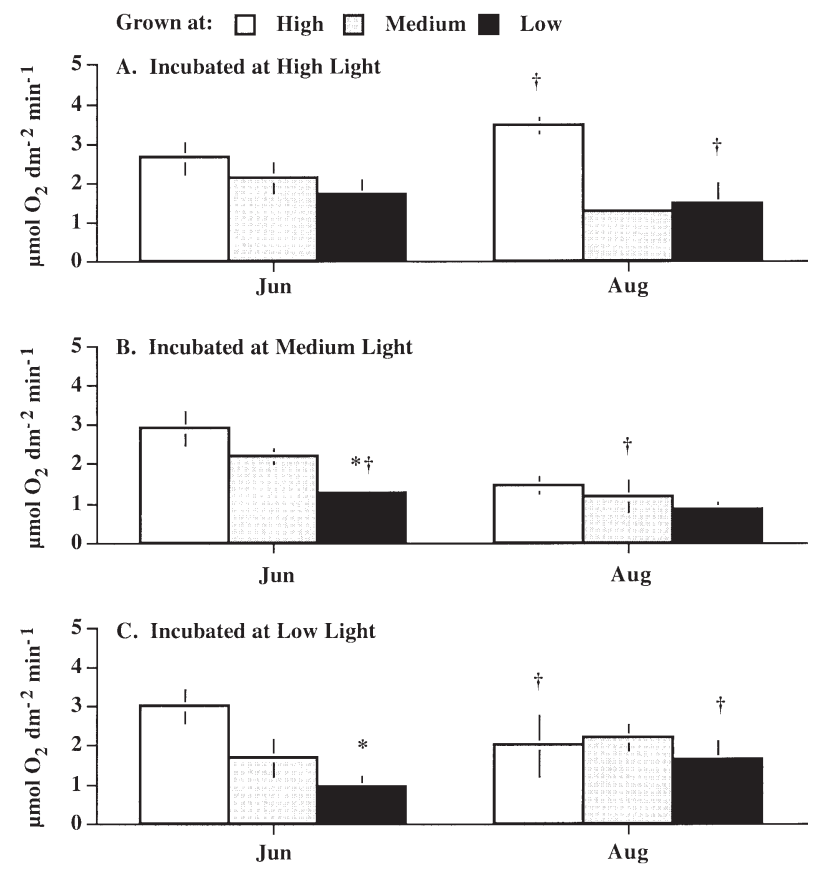

Fig. 4. Net photosynthetic production of seedlings grown in High, Medium and Low light treatments and incubated for $5 \mathrm{~h}$ at each light level. Errors represent the SE of the mean. *Indicates statistical difference between the Low and High treatment at the light level of incubation. Bars with a $\mathrm{I}$ above indicate less than 4 replicates were used to determine statistical differences. Statistical differences were calculated using an ANOVA on ranked data followed by a post hoc Bonferroni test $(\mathrm{p}<0.016)$

mg plant $\mathrm{dw}^{-1} \mathrm{~min}^{-1}$ ) among treatments during the course of the experiment.

The actual success of the photoadaptive responses of Zostera marina seedlings can be assessed by comparing photosynthetic performance of plants from each experimental shading treatment when placed in the other treatments. Calculated values of net production normalized to shoot surface area provide an index of photosynthetic performance. In June, plants grown for ca $10 \mathrm{~d}$ in low light had significantly lower photosynthetic production rates compared to plants grown for ca $10 \mathrm{~d}$ in high light when placed in medium or low light, whereas they were not different in August (Fig. 4). The inability to show a statistical difference in August may be due to low sample size $(n=2)$ in some cases coupled with high variability among individual plants. There were no significant differences in photosynthetic production rates between seedlings from any treatment when placed in any of the incubation light levels. For example, plants from the low light treatment had similar production rates whether they were placed in high, medium or low light in both June and August.

\section{DISCUSSION}

\section{Survivorship, reproduction, morphology, and growth rate}

The high survival and photosynthetic production rates of even the heavily shaded seedlings suggest that adaptive responses were adequate, at least for the first summer of growth. However, long-term vegetative survival was unlikely, since no laterals were formed and below ground biomass was severely reduced. The retardation of vegetative reproduction suggests that seedlings require a minimum of $8 \mathrm{E} \mathrm{m}^{-2} \mathrm{~d}^{-1}$ PAR on average during their first summer of growth in order to increase bed size.

Changes in specific leaf area with reduced light for adult Zostera have not been consistent (Table 5). The increase in SLA in our seedlings may be an explanation for the ability of the medium light seedlings to maintain growth rates and surface area equivalent to plants grown in high light. Thinner leaves, coupled with an increase in chlorophyll a per unit mass, would result in a decrease in the relative amount of nonphotosynthetic tissue and an increase in light absorption per unit biomass (Goldsborough \& Kemp 1988). However, while thinner leaves may increase the maximum photosynthetic rate (Enríquez et al. 1995), they may also be more prone to breakage (Kopp 1998).

Increases in chlorophyll a under conditions of reduced light, such as we found in our seedlings, are commonly reported for mature Zostera (Table 5). An increase in chlorophyll $a$ in marine macrophytes increases light absorption according to a law of diminishing returns (Enríquez et al. 1994), so that a large increase in chlorophyll a increases light absorption only marginally. This suggests that any increase in chlorophyll initiated by the most highly shaded plants could not have been sufficient to enable them to sustain growth rates and leaf initiation rates similar to plants maintained at higher light levels.

The similarity in shoot surface area between seedlings grown in high and medium light treatments is somewhat surprising, as shoots collected from the high light treatment had both more primary shoots with lateral shoots and also more laterals per primary shoot. The explanation may lie in other aspects of shoot morphology. Seedlings grown in medium light had a longer leaf lifespan, which allowed leaves to grow taller and wider, increasing surface area.

Since leaf production is directly linked to rhizome production, with each new leaf corresponding to a new rhizome node (Jacobs 1979), a longer PI results in a lower rhizome production rate and, therefore, lower below ground biomass. Lowered allocation of production to rhizomes has been reported as a consequence of 
Table 5. General results of studies on Zostera species subjected to lowered irradiance levels. +: increase, -: decrease. ns: no significant difference

\begin{tabular}{|c|c|c|c|c|c|c|c|c|c|}
\hline Source & $\begin{array}{c}\text { Leaf } \\
\text { pigments }\end{array}$ & $\begin{array}{l}\text { Growth } \\
\text { rate }\end{array}$ & PI & $\begin{array}{l}\text { Chl } a: b \\
\text { ratio }\end{array}$ & $\begin{array}{c}\text { Specific leaf } \\
\text { area: } \mathrm{dm}^{2} \mathrm{gdw}^{-1}\end{array}$ & $\begin{array}{l}\text { Lateral shoot } \\
\text { initiation }\end{array}$ & $\begin{array}{l}\text { Rhizome } \\
\text { allocation }\end{array}$ & $\begin{array}{c}\text { Shoot } \\
\text { biomass }\end{array}$ & $\mathrm{P}_{\max }$ \\
\hline Dennison \& Alberte (1982) & + & - & + & - & ns & & & + & - \\
\hline Dennison \& Alberte (1985) & + & & + & ns & - & & & ns & - \\
\hline Dennison \& Alberte (1986) & + & - & + & - & ns & & - & - & - \\
\hline Short 1991 & & - & & & & & & - & \\
\hline Olesen \& Sand-Jensen (1993) & + & - & & & + & & - & - & \\
\hline Abal et al. $(1994)^{*}$ & + & - & + & & & - & - & + & \\
\hline van Lent \& Verschuure (1994) & + & & & & & & & & \\
\hline Goodman et al. (1995) & & & & & & & & & - \\
\hline van Lent et al. (1995) & & - & & & & & & - & \\
\hline Zimmerman et al. (1995) & & - & & ns & & & & & ns \\
\hline This study & + & - & + & + & + & - & - & - & - \\
\hline${ }^{*} Z$. capricornii & & & & & & & & & \\
\hline
\end{tabular}

shading in mature Zostera marina (Table 5). Energy reserves accumulated during the summer months are crucial for support of metabolic activity and growth during the low light periods of winter and spring (Madsen 1991, Olesen \& Sand-Jensen 1993, Kraemer \& Alberte 1995, Zimmerman et al. 1995). Therefore, although seedlings grown in low light could survive an entire summer with an average daily PAR of $3.3 \mathrm{E}$ $\mathrm{m}^{-2} \mathrm{~d}^{-1}$, they would be unlikely to survive the winter due to inadequate rhizome reserves.

\section{Photosynthesis and respiration}

Short-term photosynthetic rates per unit leaf area of seedlings were 2 to 3 times higher than reported for mature Zostera, even when plants were growing at high irradiance (Dennison \& Alberte 1982, 1986, Marsh et al. 1986). A recent study of Cymodocea nodosa reported higher PAR saturated photosynthetic rates (and higher respiration rates) in seedlings versus lateral or primary shoots (Nielsen \& Pederson 2000). They attributed this difference to greater nutrient availability in seedling patches compared to larger adult meadows, however they did not address the issue of self-shading within established meadows. The reduction in net photosynthetic rates in plants grown in low light even when temporarily subjected to high light implies that they are unable to exploit short-term increases in light that occur in estuarine habitats.

Dennison \& Alberte (1982) found that when plants received $100 \mu \mathrm{E} \mathrm{m}^{-2} \mathrm{~s}^{-1}$ less than $10 \mathrm{~h} \mathrm{~d}^{-1}$, growth rates were strongly affected. When they received less than $6 \mathrm{~h}$, both growth and survival were compromised. During our experiment, growth rates of seedlings experi- encing $8 \mathrm{~h}$ of $100 \mu \mathrm{E} \mathrm{m} \mathrm{m}^{-2} \mathrm{~s}^{-1} \mathrm{~d}^{-1}$ were unaffected, but they were seriously reduced when the plants only received $4 \mathrm{~h} \mathrm{~d}^{-1}$. This suggests that the length of time seedlings are exposed to light may be as important as the fraction of incident light they receive.

\section{CONCLUSIONS}

Decreases in light availability had effects on Zostera marina seedlings that are summarized in Fig. 5. In the field, the survival of planted or naturally occurring patches of seedlings depends on growth, mortality, and reproduction of the population. In this study, although survival was high even at very low light, above and below ground growth rates, and vegetative reproduction were negatively affected. Our results suggest that seedlings need considerably greater than $4 \mathrm{~h}$ of irradiance exceeding $100 \mu \mathrm{E} \mathrm{m}^{-2} \mathrm{~s}^{-1}$, and greater than $8 \mathrm{E} \mathrm{m}^{-2} \mathrm{~d}^{-1}$ mean daily PAR during their first summer of growth to become established perennial beds. Our results also indicate that rapid vegetative expansion of patches composed of seedlings can only occur at relatively high light intensities. Although some expansion can occur at a mean summer PAR of $8 \mathrm{E} \mathrm{m}^{-2} \mathrm{~d}^{-1}$, seedlings are more likely to invest energy in longer and wider leaves, rather than in lateral shoot production. Additionally, the increase in SLA (thinner leaves) and the decrease in below ground material may have consequences for seedling survival in the field. Thinner leaves are more susceptible to breakage and low below ground biomass may decrease anchoring capacity and nutrient acquisition. When mean daily quantum flux drops to $3.3 \mathrm{E} \mathrm{m}^{-2} \mathrm{~d}^{-1}$ during the first summer of growth, the potential for multi-year seedling survival is low. 
(a)

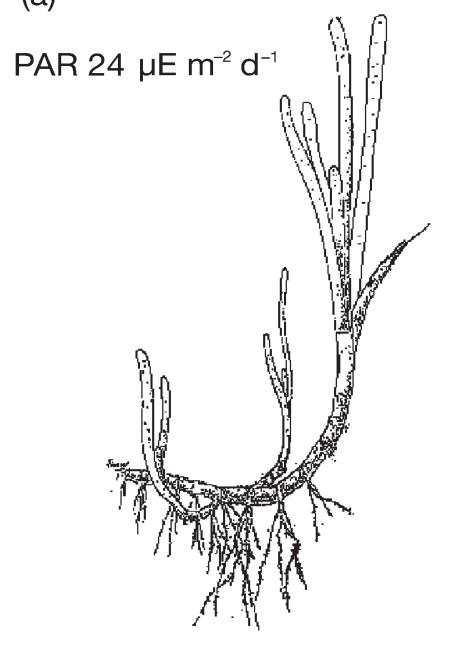

(b)

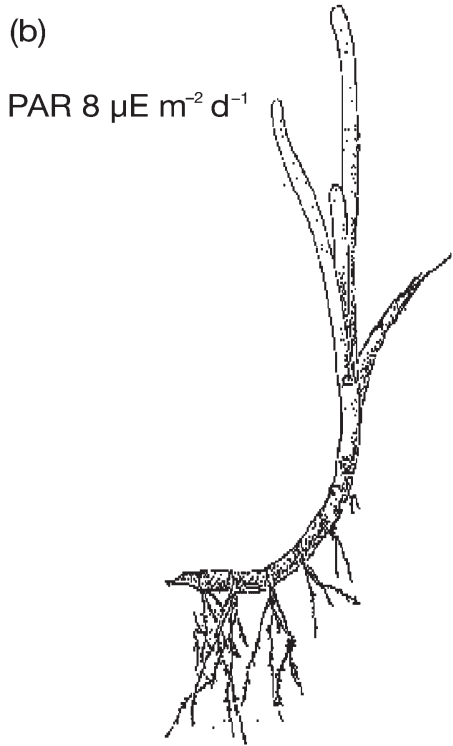

(c)

PAR $3 \mu \mathrm{E} \mathrm{m}^{-2} \mathrm{~d}^{-1}$

Fig. 5. Summary of seedling response to $12 \mathrm{wk}$ of growth at High, Medium and Low light. Values for daily PAR are means for the $12 \mathrm{wk}$ period. Drawings adapted from Thayer et al. (1984). (a) $100 \%$ survival, $85 \%$ produce lateral shoots, large shoots by weight, high below ground biomass, equal weight allocation above and below ground, $4-5$ leaves per primary shoot, low area per unit biomass, rapid primary shoot growth rate, rapid rhizome production rate, short PI, high chl $a$ : $b$ ratio; (b) $94 \%$ survival, $29 \%$ produce lateral shoots, 3-4 leaves per primary shoot, long, thin and wide leaves, rapid primary shoot growth rate, long PI, low pigment concentrations, low chl $a: b$ ratio; (c) $74 \%$ survival, no lateral shoots, small shoots by weight and area, low below ground biomass, greater biomass allocation above than below ground, 3 leaves per primary shoot, narrow leaves, slow primary shoot growth rate, slow rhizome production rate, long PI, high pigment concentration

Acknowledgements: We acknowledge and thank S. Granger, S. Sherwood, B. Buckley and M. Brush for technical and scientific advice throughout the experiment, and S. Granger and M. Traber for seed collection and separation. We would also like to thank Dr V. de Jonge and the anonymous reviewers who provided very helpful comments on this manuscript. Rhode Island Sea Grant provided funding for this research

\section{LITERATURE CITED}

Abal EG, Loneragan N, Bowen P, Perry CJ, Udy JW, Dennison WC (1994) Physiological and morphological responses of the seagrass Zostera capricornii Aschers. to light intensity. J Exp Mar Biol Ecol 178:113-129

Backman TW, Barilotti DC (1976) Irradiance reduction: Effects on standing crops of the eelgrass Zostera marina in a coastal lagoon. Mar Biol 43:33-40

Bulthuis DA (1983) Effects of in situ light reduction on density and growth of the seagrass Heterozostera tasmanica (Martens ex Aschers) den Hartog in Western Port, Victoria, Australia. J Exp Mar Biol Ecol 61:91-103

Churchill AC (1983) Field studies on seed germination and seedling development in Zostera marina L. Aquat Bot 1: 21-29

Cody RP, Smith JK (1997) Applied statistics and the SAS programming language. Prentice Hall, NJ, USA

de Jonge VN, de Jong DJ, van den Bergs J (1996) Reintroduction of eelgrass (Zostera marina) in the Dutch Wadden Sea; review of research and suggestions for management measures. J Coast Cons 2:149-158

de Jonge VN, de Jong DJ, van Katwijk MM (2000) Policy plans and management measures to restore eelgrass
(Zostera marina L.) in the Dutch Wadden Sea. Helgol Mar Res 54:151-158

Dennison WC (1990) Chlorophyll content. In: Phillips RC, MCRoy CP (eds) Seagrass Research Methods. UNESCO, Paris

Dennison WC, Alberte RS (1982) Photosynthetic responses of Zostera marina L. (eelgrass) to in situ manipulations of light intensity. Oecologia 55:137-144

Dennison WC, Alberte RS (1985) Role of daily light period in the depth distribution of Zostera marina (eelgrass). Mar Ecol Prog Ser 25:51-61

Dennison WC, Alberte RS (1986) Photoadaptation and growth of Zostera marina L. (eelgrass) transplants along a depth gradient. J Exp Mar Biol Ecol 98:265-282

Dennison WC, Orth RJ, Moore KA, Stevenson JC, Carter V, Kollar S, Bergstrom PW, Batiuk R (1993) Assessing water quality with submersed aquatic vegetation. Bioscience 43(2):86-94

Duarte, CM (1991) Seagrass depth limits. Aquat Bot 40: 363-378

Duarte CM, Sand-Jensen K (1990) Seagrass colonization: patch formation and patch growth in Cymodocea nodosa. Mar Ecol Prog Ser 65:183-191

Enríquez S, Agustí S, Duarte CM (1994) Light absorption by marine macrophytes. Oecologia 98:121-129

Enríquez S, Duarte CM, Sand-Jensen K (1995) Patterns in the photosynthetic metabolism of Mediterranean macrophytes. Mar Ecol Prog Ser 119:243-252

Fishman JR, Orth RJ (1996) Effects of predation on Zostera marina L. seed abundance. J Exp Mar Biol Ecol 198:11-26

Goldsborough WJ, Kemp WM (1988) Light responses of a submersed macrophyte: implications for survival in turbid tidal waters. Ecology 69(6):1775-1786

Goodman JL, Moore KA, Dennison WC (1995) Photosynthetic 
responses of eelgrass (Zostera marina) to light and sediment sulfide in a shallow barrier island lagoon. Aquat Bot 50:37-47

Granger SL, Traber MS, Nixon SW (2000) Propagation of Zostera marina L. from seed. In: Sheppard C (ed) Seas at the millennium: an environmental evaluation. Elsevier Science, Oxford, p 55-58

Harlin MM, Thorne-Miller B, Boothroyd J (1982) Seagrasssediment dynamics of a flood-tidal delta in Rhode Island (USA). Aquat Bot 14:127-138

Harrison PG (1987) Natural expansion and experimental manipulation of seagrass (Zostera sp.) abundance and the response of infaunal invertebrates. Estuar Coast Shelf Sci 24:799-812

Harrison PG (1991) Mechanisms of seed dormancy in an annual population of Zostera marina (eelgrass) from The Netherlands. Can J Bot 69:1972 -1976

Harwell MC, Orth RJ (1999) Eelgrass (Zostera marina L.) seed protection for field experiments and implications for largescale restoration. Aquat Bot 64:51-61

Hootsmans MJM, Vermaat JE, van Vierssen W (1987) Seedbank development, germination and early seedling survival of two seagrass species from the Netherlands: Zostera marina L. and Zostera noltii Hornem. Aquat Bot 28:275-285

Jacobs RPWM (1979) Distribution and aspects of the production and biomass of eelgrass, Zostera marina L. at Roscoff, France. Aquat Bot 7:151-172

Keddy CJ, Patriquin DG (1978) An annual form of eelgrass in Nova Scotia. Aquat Bot 5:163-170

Kentula ME, McIntire CD (1986) The autecology and production dynamics of eelgrass (Zostera marina L.) in Netarts Bay, Oregon. Estuaries 9(3):188-199

Kopp BS (1998) Effects of nitrate fertilization and shading on physiological and biomechanical properties of eelgrass (Zostera marina L.). PhD thesis, University of Rhode Island

Kraemer GP, Alberte RS (1995) Impact of daily photosynthetic period on protein synthesis and carbohydrate stores in Zostera marina L. (eelgrass) roots: implications for survival in light limited environments. J Exp Mar Biol Ecol 185: 191-202

Madsen JD (1991) Resource allocation at the individual plant level. Aquat Bot 41:67-86

Marsh JA, Dennison WC, Alberte RS (1986) Effects of temperature on photosynthesis and respiration in eelgrass (Zostera marina L.). J Exp Mar Biol Ecol 101:257-267

McMillan C (1983) Seed germination for an annual form of Zostera marina from the Sea of Cortez, Mexico. Aquat Bot 16:105-110

Nielsen SO, Pedersen MF (2000) Growth, photosynthesis and nutrient content of seedlings, and mature plants of Cymodocea nodosa - the importance of clonal integration. Aquat Bot 68:265-271

Editorial responsibility: Victor de Jonge (Contributing Editor), Haren, The Netherlands
Olesen B (1999) Reproduction in Danish eelgrass (Zostera marina L.) stands: size-dependence and biomass partitioning. Aquat Bot 65:209-219

Olesen B, Sand-Jensen K (1993) Seasonal acclimation of eelgrass Zostera marina growth to light. Mar Ecol Prog Ser 94:91-99

Olesen B, Sand-Jensen K (1994a) Patch dynamics of eelgrass Zostera marina. Mar Ecol Prog Ser 106:147-156

Olesen B, Sand-Jensen K (1994b) Demography of shallow eelgrass (Zostera marina) populations: shoot dynamics and biomass development. J Ecol 82:379-390

Orth RJ, Moore KA (1983) Seed germination and seedling growth of Zostera marina L. (eelgrass) in the Chesapeake Bay. Aquat Bot 15:117-131

Orth RJ, Luckenbach M, Moore KA (1994) Seed dispersal in a marine macrophyte: implications for colonization and restoration. Ecology 75:1927-1939

Phillips RC, Grant WS, McRoy CP (1983) Reproductive strategies of eelgrass (Zostera marina L.). Aquat Bot 16:1-20

Robertson AI, Mann KH (1984) Disturbance by ice and lifehistory adaptations of the seagrass Zostera marina. Mar Biol 80:131-141

Short FT (1991) Light limitation on seagrass growth. In: Kenworthy WJ, Haunert DE (eds) The light requirements of seagrasses: proceedings of a workshop to examine the capability of water quality criteria, standards and monitoring programs to protect seagrasses. NOAA Technical Memorandum NMFS-SEFC-287, NOAA, Washington, DC

SPSS Inc. (1998) SYSTAT 8.0 Statistics. SPSS Inc., USA

Thayer GW, Kenworthy WJ, Fonseca MS (1984) The ecology of eelgrass meadows of the Atlantic coast: a community profile. FWS/OBS-84/02. US Fish and Wildlife Service, Washington, DC

van Katwijk MM, Schmitz GHW, Hanssen LSAM, den Hartog C (1998) Suitability of Zostera marina populations for transplantation to the Wadden Sea as determined by a mesocosm shading experiment. Aquat Bot 60:283-305

van Katwijk MM, Hermus DCR, de Jong DJ, Asmus RM, de Jonge VN (2000) Habitat suitability of the Wadden Sea for restoration of Zostera marina beds. Helgol Mar Res 54: $117-128$

van Lent F, Verschuure JM (1994) Intraspecific variability of Zostera marina L. (eelgrass) in the estuaries and lagoons of the southwestern Netherlands. I. Population dynamics. Aquat Bot 48:31-58

Zimmerman RC, Alberte RS (1996) Effect of light/dark transition on carbon translocation in eelgrass Zostera marina seedlings. Mar Ecol Prog Ser 136:305-309

Zimmerman RC, Reguzzoni JL, Alberte RS (1995) Eelgrass (Zostera marina L.) transplants in San Francisco Bay: role of light availability on metabolism, growth and survival. Aquat Bot 51:67-86

Submitted: June 12, 1999; Accepted: April 3, 2001

Proofs received from author(s): November 15, 2001 